\title{
Improving 4c Skills and Student Learning Outcomes through Device Assisted Creative Problem Solving (CPS) Learning Models on Static Electricity Topics
}

Juni Angkowati

Master of Natural Science Education and Teacher of SMP Negeri 1 Paringin, Batu Piring Village, South Paringin District, Balangan Regency, South Kalimantan Province, Indonesia

DOI: $10.36348 /$ jaep.2020.v04i11.005

| Received: 29.10.2020 | Accepted: 12.11.2020 | Published: 17.11.2020

*Corresponding author: Juni Angkowati

\section{Abstract}

Education in the $21^{\text {st }}$ century where information technology can become the basis of information in the world of education, so it requires teachers and students to be critical and creative. Science learning cannot be separated from $21^{\text {st }}$ century skills known as 4C skills (Creativity Thinking, Critical Thinking, Communication, and Collaboration). The problem faced by researchers as science teachers is the lack of $4 \mathrm{C}$ skills of $9^{\text {th }}$ grade students, especially on the topic of electricity resulting in low learning outcomes of students. The solution to fix these problems, the teacher applies learning using the Creative Problem Solving (CPS) model with the help of a device or cellphone. Given that almost all students already have this device. This research is a classroom action research (PTK) with two cycles, each cycle consisting of two meetings. Based on the research results it can be concluded that $4 \mathrm{C}$ skills, namely Creativity Thinking in the first cycle an average of $85 \%$ and the second cycle of $96.25 \%$. Critical Thinking in the first cycle an average of $86.75 \%$ and the second cycle of $98 \%$. Communication the first cycle average of $89 \%$ and the second cycle of $98.50 \%$. Collaboration average for the first cycle was $84.75 \%$ and the second cycle was $97.50 \%$. The learning outcomes of students in the first cycle of learning completeness were $70.97 \%$, while in the second cycle it was $90.32 \%$. There are still three students who have not finished receiving remedials. Learning using the CPS learning model with device assistance gets a positive response from all students.

Keywords: 4c skills, learning outcomes, creative problem solving, devices.

Copyright (C) 2020 The Author(s): This is an open-access article distributed under the terms of the Creative Commons Attribution 4.0 International License (CC BY-NC 4.0) which permits unrestricted use, distribution, and reproduction in any medium for non-commercial use provided the original author and source are credited.

\section{INTRODUCTION}

The $21^{\text {st }}$ century is marked by the large number of (1) information available anywhere and can be accessed at any time; (2) faster computing; (3) automation that replaces routine jobs; and (4) communication that can be done from anywhere and anywhere [1]. 21st Century competence demands that the world of education integrate knowledge skills, skills and attitudes, as well as mastery of Information and Communication Technology (ICT). The world of education is required to produce students who are able to face global challenges.

There are many programs provided by the government to improve the quality of teaching, namely providing facilities and infrastructure assistance in schools called BOS (School Operational Assistance). Among them in improving the quality of learning, schools must provide textbook loans. Textbooks are used to increase the efficiency and effectiveness of learning, the number of which is adjusted to the needs of students [2].

Teaching in the $21^{\text {st }}$ century that is very helpful is the subject of Natural Sciences, because many abstract materials can be made real with the help of digital technology, especially electrical materials. Students can learn easily and without limits, so that teachers are not the only source of knowledge transformation. Science is a subject that is included in the national exam (UNBK), static electricity is a physics material that is always on the national exam. And static electricity is electrical material at the beginning in $9^{\text {th }}$ grade. With today's technology, abstract material can be made real. At SMP Negeri 1 Paringin, it has quite complete facilities compared to other schools, including science teachers according to their discipline of knowledge, each student gets a textbook loan for all subjects, the library already has 
more than 1,700 books, the internet network is quite smooth. With these facilities, it is hoped that the learning process will be smoother and easier, so that the National Examination score should be above the specified KKM which is 5.5.

The fact that so far the average UNBK score in science subjects in $9^{\text {th }}$ grade for the 2018/2019 academic year is still low, namely 48.33 with 103 students. Of the 103 people who attended UNBK, only 33 people or about $23 \%$. Students, especially grade 9 students, never use the school library in empty class hours, this is evidenced by the absence of the names of $9^{\text {th }}$ grade students who fill in guest books in the library.

The subject matter in $9^{\text {th }}$ grade that still needs to be improved is most of the physics material, one of which is Static Electricity with KKM 70. In the previous academic year, researchers who were also science teachers who had tried to use experimental methods turned out to require a lot of time, students could not streamline their time., the complete individual student learning outcomes are only $40 \%$ of the 30 people, while the practical completeness has not reached $80 \%$. There are still many students who are not critical in thinking, are not creative, and most students have never read before doing an experiment so that many experiments are carried out that are not according to the procedure.

Based on experiences that have been applied and have not obtained maximum results, the teachers in this study changed the learning method. Researchers used Creative Problem Solving Learning (CPS) with the help of a device or cellphone. The reason researchers use the Creative Problem Solving (CPS) learning model is in accordance with the demands of making students able to find and solve problems well. Problem solving involves critical thinking skills. The learning model is called a conceptual model with three process components, namely understanding challenges, generating ideas, and preparing for action [3].

Learning Model Creative problem solving is not only to solve problems but creativity is very much needed in the CPS learning model. Creative thinking is part of higher order thinking or Higher Order Thinking Skill (HOTS) [4]. Students must be creative because they need ideas or ideas to find ideas in choosing the best solution. Meanwhile, the ability to get ideas or ideas is needed for critical thinking skills.

In accordance with 21 st century learning, where difficult learning can be assisted by using digital technology, the researchers use the media devices or cellphones that students already have so that the learning atmosphere of students varies. With mentoring and monitoring of teachers as researchers because so far students are prohibited from carrying devices or cellphones if they are not asked by the teacher.
Teaching using the Creative Problem Solving (CPS) learning model with the help of media devices is expected to make students more challenged, happier, more critical and creative. So that it can increase the competence of 4C skills, namely Creativity Thinking, Critical Thinking, Communication, and Collaboration. With the increase in the $4 \mathrm{C}$ competence of students increasing, it can be balanced with the increase in student learning outcomes in the subject of static electricity.

\section{RESEARCH METHODS}

Researchers used a qualitative approach in this classroom action research. Data obtained from qualitative research such as results of observations, interviews, documentation, written excerpts from documents and field notes are not written in statistical form and numbers. Researchers carry out data analysis by enriching information and through comparative analysis as long as they do not eliminate the original data. The data collected and reviewed in this study are qualitative and quantitative data. Data obtained from various sources, namely teachers, students, documents on learning outcomes, and the learning process. The data collection instruments in this study were in the form of observation sheets to measure the competence of $4 \mathrm{C}$ skills, learning outcomes tests (evaluation cycle 1 and 2) to measure student learning outcomes, and questionnaires to determine student responses. Data analysis was carried out descriptively qualitatively and quantitatively. This analysis aims to determine the competence of $4 \mathrm{C}$ skills and learning outcomes, and students' responses to learning activities. The learning outcomes in this study include the cognitive and psychomotor domains. Student learning outcomes data in the cognitive domain were obtained from the results of written tests, namely the evaluation of learning cycle 1 and cycle 2 . Whereas in the psychomotor realm, the $4 \mathrm{C}$ skill competency was obtained from the observation sheet.

The presence of researchers in the implementation of this Classroom Action Research is as a science subject teacher, a teacher at $9^{\text {th }}$ grade in SMP Negeri 1 Paringin. Researchers collaborate with other science subject teachers to solve problems that arise during the learning process. The problem that will be corrected by researchers in teaching science at semester odd is static electricity. In addition to improving learning outcomes, researchers also improve the competency of 4C skills (critical thinking, creativity. Communication, and collaboration). Even though textbooks have been lent to each student, there has been no progress in improving learning outcomes. The role of the science subject teacher and at the same time as a researcher collaborates with other science teachers to solve these problems by improving the learning model commonly used. The learning model that will be used is Creative Problem Solving (CPS), in order to increase 
the motivation of students in the learning process, it can be assisted with devices.

The research subjects were class 9-B, with a total of 31 students. The number of female students was 19 and the number of male students was 12. All students get textbook loans, especially science student books. The characteristics of grade 9-B students are only a small proportion who want to read books when given a teacher's assignment, students are lazy to read so they ask a lot of questions. Some students are not enthusiastic, some talk a lot and disturb their friends in class during the learning process. When getting homework that is recommended to complete by looking for information on the internet, many students do not do it.

This study uses a classroom action research design whose steps follow the flow of the Mc. Taggart. The stages are planning, action, observation and reflection in each cycle, as in Figure-1.

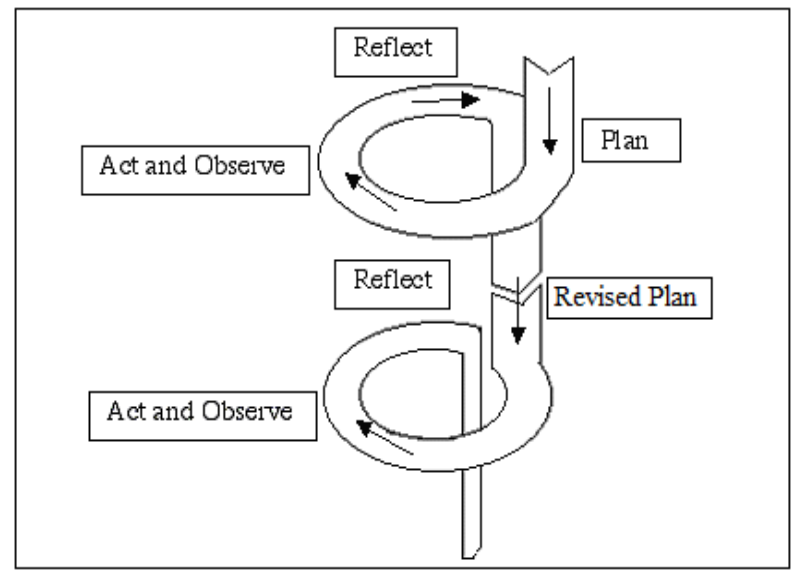

Fig-1: Model Spiral Kemmis dan Taggart (1988) [5]

Performance indicators to determine the success of this Classroom Action Research, the authors set performance indicators:

1. Students' $4 \mathrm{C}$ skills are good category.

2. The average test score for student learning outcomes is the same as or above the KKM score, which is 70. Students who score the same or above the KKM are at least $80 \%$.

3. Student responses to learning the CPS model of device assistance are on average positive or very good.

\section{RESEARCH RESULTS \\ Observation Cycle 1}

Observations that have been made by researchers and observers during the cycle I process obtain the following data:

\section{C skills}

Table-1: 4C skills data

\begin{tabular}{|l|l|l|l|l|}
\hline \multirow{2}{*}{ No. } & 4C skills & \multicolumn{3}{|c|}{ Percentage of Cycle I } \\
\cline { 3 - 5 } & $\begin{array}{l}\mathbf{1}^{\text {st }} \\
\text { Meeting }\end{array}$ & $\begin{array}{l}\mathbf{2}^{\text {nd }} \\
\text { Meeting }\end{array}$ & Average \\
\hline 1 & $\begin{array}{l}\text { Creativity } \\
\text { Thinking }\end{array}$ & 82.25 & 88 & 85 \\
\hline 2 & $\begin{array}{l}\text { Critical } \\
\text { Thinking }\end{array}$ & 83 & 90.25 & 86.75 \\
\hline 3 & Communication & 86.25 & 92 & 89 \\
\hline 4 & Collaboration & 80.75 & 88.75 & 84.75 \\
\hline
\end{tabular}

Based on the data in Table-1, the overall $4 \mathrm{C}$ skills competency of students is good, but in cycle I there are five students who need special attention. There is one student who is always supervised because in the learning process he can open WhatsApp (WA) on his device or can take selfies. Two more people often invite their friends to chat outside the context of learning, one more person is less active, and one person often hangs his head at the table during the first meeting, after being asked by the teacher it turns out that the student is sick. At the second meeting, these students were very active.

\section{Learning Outcomes}

Table-2: Cycle 1 learning outcome data

\begin{tabular}{|l|l|l|l|}
\hline \multirow{2}{*}{ No. } & \multicolumn{3}{|l|}{ Minimum Mastery Criteria (KKM) = 70 } \\
\cline { 2 - 4 } & $\begin{array}{l}\text { Value } \\
\text { Interval }\end{array}$ & $\begin{array}{l}\text { The number of } \\
\text { students }\end{array}$ & Information \\
\hline 1 & $\geq 90-100$ & - & Mastery \\
\hline 2 & $\geq 80-90$ & 4 & Mastery \\
\hline 3 & $\geq 70-80$ & 18 & Mastery \\
\hline 4 & $\geq 70$ & 9 & Not Mastery \\
\hline & & 31 & \\
\hline
\end{tabular}

After cycle 1 is complete, students take a written test, namely working on the evaluation sheet of cycle 1 to find out the learning outcomes, then the learning outcomes are analyzed, which results have not reached the research objectives.

\section{Observation Cycle 2}

Observations during the cycle 2 process by researchers assisted by observers obtain the following data. 
4C skills

Table-3: 4C skills data
\begin{tabular}{|l|l|l|l|l|}
\hline \multirow{2}{*}{ No. } & \multirow{2}{*}{ 4C skills } & Percentage of Cycle I \\
\cline { 3 - 5 } & & $\mathbf{1}^{\text {st }}$ Meeting & $\mathbf{2}^{\text {nd }}$ Meeting & Average \\
\hline 1 & Creativity Thinking & 96.75 & 96.75 & 96.25 \\
\hline 2 & Critical Thinking & 97.50 & 98.5 & 98.00 \\
\hline 3 & Communication & 97.50 & 100 & 98.50 \\
\hline 4 & Collaboration & 96.75 & 97.50 & 97.50 \\
\hline
\end{tabular}

Based on data 3, the average skill of $4 \mathrm{C}$ cycle 2 is getting better than the previous cycle.

\section{Learning Outcomes}

Table-4: Cycle 2 learning outcome data

\begin{tabular}{|l|l|l|l|}
\hline \multirow{2}{*}{ No. } & \multicolumn{3}{|l|}{ Minimum Mastery Criteria (KKM) $=\mathbf{7 0}$} \\
\cline { 2 - 4 } & $\begin{array}{l}\text { Value } \\
\text { Interval }\end{array}$ & $\begin{array}{l}\text { The number of } \\
\text { students }\end{array}$ & Information \\
\hline 1 & $\geq 90-100$ & - & Mastery \\
\hline 2 & $\geq 80-90$ & 3 & Mastery \\
\hline 3 & $\geq 70-80$ & 25 & Mastery \\
\hline 4 & $\geq 70$ & 3 & \\
\hline & & 31 & \\
\hline
\end{tabular}

\section{Student Response}

Measuring student responses by distributing response questionnaires to all students ( 31 people) after all the actions in the learning process cycle 1 and cycle
2 are complete. This questionnaire aims to determine the reactions of students to the learning provided by the teacher. The student response questionnaire data are as follows.

Table-5: Student response data

\begin{tabular}{|l|l|l|l|}
\hline \multirow{2}{*}{ No. } & \multirow{2}{*}{ Statement } & \multicolumn{2}{|l|}{ The number of students } \\
\cline { 3 - 4 } & & Yes & No \\
\hline 1 & Happiness & 31 & 0 \\
\hline 2 & Excited & 31 & 0 \\
\hline 3 & Easier & 31 & 0 \\
\hline 4 & Effective & 31 & 0 \\
\hline 5 & Efficient & 31 & 0 \\
\hline 6 & High curiosity & 31 & 0 \\
\hline \multicolumn{2}{|l|}{ Total } & 31 & \\
\hline
\end{tabular}

Based on Table-4, where the number of students in the research subject was 31 people and all of them gave the answer "Yes". This shows that all students agree and respond very well to learning.

\section{Reflection}

Based on the presentation of cycle 2 action data, the results are better than the previous cycle, including:

a. The 4C skills competency of students is getting better, although there are still three students who still have difficulty developing their ideas.

b. The learning outcomes of individual and classical mastery students have increased, although there are still three students who have not completed. The three students will be rememedial on sub material that they do not understand.

c. Even though the learning completeness is not $100 \%$, all of the students' responses are very good for learning CPS assisted by device.

\section{Comparison of Cycle 1 and Cycle 2 4C competence}

Based on data exposure during the learning process cycle 1 and cycle 2, the comparison of the observation results of 4C skills (Creativity Thinking, Critical Thinking, Communication, and Collaboration) can be illustrated in Figure-2.

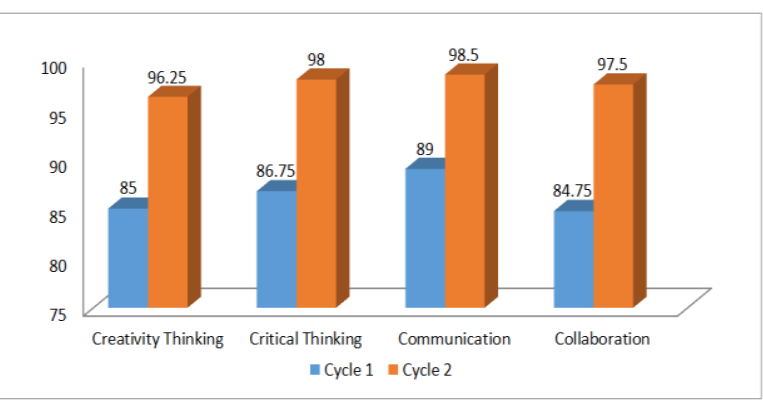

Fig-2: 4C skills comparison 


\section{Learning Outcomes}

Based on the analysis of learning evaluation conducted by researchers in cycle I and cycle II, it shows a comparison that can be described in Figure-3.

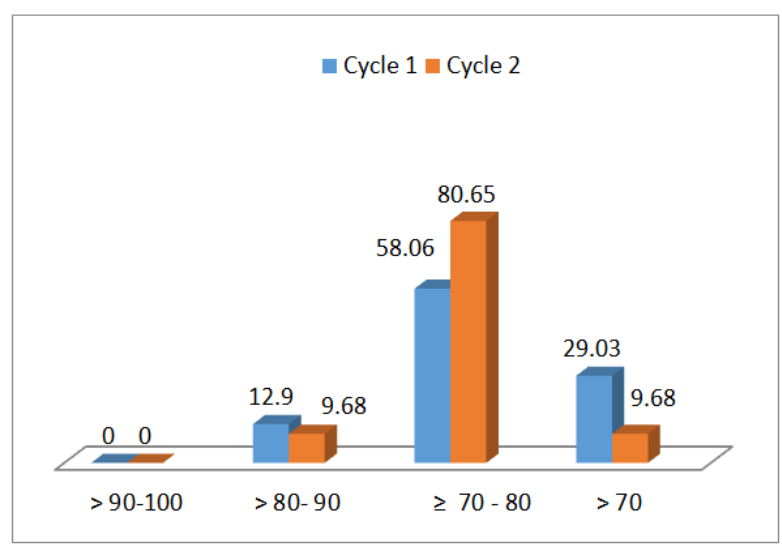

Fig-3: Comparison of learning outcomes

\section{Research Findings}

Researchers assisted by observers during the learning process found findings in the study, including:

\section{Cycle 1}

The learning process at the first and second meetings, students were very enthusiastic about learning using a device (cellphone). Because so far school regulations do not allow students to bring gadgets. After they brought the device, their curiosity was very high. But there are some students who in the learning process open applications or sites outside the context of learning. Qualitative data in this study are from observations of teacher activity and $4 \mathrm{C}$ skills. The learning implementation of the CPS learning model with device assistance has been carried out very well by the teacher as a researcher. Meanwhile, 4C skills (creative, critical, communication, and collaboration) are on average very good. Although there are some students who have not maximized on this skill. Student learning outcomes still have not reached the specified target. Students are declared to have mastered the lesson if they get the same learning score or more than 70. In cycle 1 there are still as many as seven people who have not mastered the lesson.

\section{Cycle 2}

The learning process in cycle 2 at the first and second meetings was still very enthusiastic in solving the problems given by the teacher by completing worksheets. Time is very effective and efficient. Learning outcomes have met the target indicators of success.

\section{DISCUSSION}

This research was conducted to solve the problem of static electricity in class 9-B. Static electricity is the initial material for electricity, if students do not understand this material, other electrical materials will experience difficulties. The problem that the researchers encountered was the activity of students who showed very low high-order thinking activities and learning outcomes of students with classical completeness were still $40 \%$. Based on the above problems, the researcher solved this problem by changing the way of learning, namely by using the CPS learning model with the help of a device (cellphone). As concluded by Fatimah \& Mufti [6] that learning using Android-based smartphone media can improve students' critical thinking skills very well.

Based on data exposure and research findings, 4C skills namely Creativity Thinking, Critical Thinking, Communication, and Collaboration in students have been good and getting better in cycle 2 . In line with the research of Triyono et al., [7] concluded that the CPS-based learning model has a positive influence on students' creativity and innovation abilities. Moreover, learning CPS with the help of media devices will speed up problem solving. CPS allows students to become skilled in finding the best solution quickly [8].

The application of CPS learning with the help of media devices can improve critical and creative thinking of students at SMPN 1 Paringin in choosing solutions and developing ideas for problem solving. In accordance with Redhana's research, 2019, namely learning will be more optimal by applying problembased learning models such as CPS to improve $21^{\text {st }}$ century skills consisting of critical thinking and problem solving skills, creativity and innovation, collaboration, and communication.

Learning CPS with the help of mobile media is able to improve student learning outcomes on static electricity material at SMPN 1 Paringin. In line with the research of Maulidina et al., [9] concluded that the Creative Problem Solving (CPS) learning model could improve the learning outcomes of Colomadu State Senior High School students on the subject matter of thermochemistry. The CPS learning model is very effective and improves learning outcomes in the respiratory system at SMAN 1 Jatibarang Brebes [10].

Based on the results of the student response questionnaire, the CPS learning device assistance was applied to static electricity material at $100 \%$ which was very good or positive. Learning with the CPS model assisted by the device makes students very happy, very easy, very motivated, very efficient, very effective, and very high curiosity. The results are the same as the research of Setyawati [11] which reports that the results of student responses are $100 \%$ giving a positive response to the application of CPS-based worksheets on environmental change and waste recycling.

The advantage of implementing the CPS learning model with device assistance on static electricity can help the learning process run smoothly, 
students can choose and develop ideas to solve problems. Students are more enthusiastic about collaborating and communicating to complete tasks. The constraints faced by researchers during the learning process using the CPS model with the help of a device were that in cycle I the researcher did not limit the use of devices, because students were very enthusiastic and curious, so they could be slow to complete the assignment given by the teacher. Students are confused about determining the solution to the problem because too much insight is obtained from the site they open from the device. Students still cannot take advantage of the time given by the teacher in solving the problems given. So that teachers need to limit the sites that students have to open so that time management is even more efficient. In the first cycle of meeting 2, there was a problem with electrical damage so that the LCD (projector) and its media could not be displayed.

\section{CONCLUSION}

1. The 4C skills (Creativity Thinking, Critical Thinking, Communication, and Collaboration) of students in cycle 1 have good results, while in cycle 2 the results are better. Creativity Thinking in cycle 1 an average of $85 \%$ and cycle 2 of $96.25 \%$, Critical Thinking cycle 1 an average of $86.75 \%$ and cycle 2 of $98 \%$, Communication of an average cycle 1 of $89 \%$ and cycles 2 of $98.50 \%$. Collaboration cycle 1 average amounted to $84.75 \%$ and cycle 2 amounted to $97.50 \%$.

2. The learning outcomes of students in cycle 1 learning completeness amounted to $70.97 \%$ while in cycle 2 was $90.32 \%$. There are still three students who have not completed and will receive remedials.

3. Learning using the CPS learning model with device assistance gets a positive response from all students.

\section{REFERENCES}

1. Kemdikbud, L. (2013). Kurikulum 2013: Pergeseran paradigma belajar abad-21. Jakarta, Juni.
2. Permendikbud, L. (2016). Peraturan Menteri Pendidikan dan Kebudayaan Republik Indonesia Nomor 20 Tahun 2016 Tentang Standar Kompetensi Lulusan Pendidikan Dasar dan Menengah. Jakarta: Menteri Pendidikan Nasional.

3. Treffinger, D. J., \& Isaksen, S. G. (2005). Creative problem solving: The history, development, and implications for gifted education and talent development. Gifted Child Quarterly, 49:342.

4. Brookhart, S. M. (2010). How to assess higher order thinking skills in your classroom. Alexandria, VA: ASCD.

5. Kemmis, S. Dan Taggart, R. 1988. The Action Reaserch Planner.

6. Fatimah, S., \& Mufti, Y. (2014). Pengembangan Media Pembelajaran IPA-Fisika Smartphone berbasis Android Sebagai Penguat Karakter Sains Siswa. Jurnal Kaunia, 10(1).

7. Triyono, S. J., \& Wilujeng, I. (2017). Pengaruh Pembelajaran Ipa Berbasis Creative Problem Solving Terhadap Kreativitas Siswa SMP. Jurnal Kependidikan, 1(2):214-226.

8. Lin, Y. S. (2011). Fostering creativity through education-a conceptual framework of creative pedagogy. Creative Education, 2(3), 149.

9. VIA Maulidina, N. A. D. Y. A., \& Hidayatullah, H. (2013). Pengaruh Current Ratio, Debt to Equity Ratio dan Earning Per Share Terhadap Nilai Perusahaan Manufaktur yang Terdaftar di Bursa Efek Indonesia (Doctoral dissertation, BINUS).

10. Musytafizur, I. Z., \& Supriyanto. (2014). Efektivitas Model Pembelajaran Creative Problem Solving Pada Materi Sistem Pernapasan Di SMAN 1 Jatibarang Brebes. Unnes Journal of Biology Education. 3(3).

11. Setyawati. (2016). Penerapan Lks Berbasis Cps Materi Perubahan Lingkungan Dan Daur Ulang Limbah Untuk Mencapai Ketuntasan Hasil Belajar. Jurnal Bioedu, 5(2). http://ejournal.unesa.ac.id/index.php/bioedu. 